\title{
Plebiscite or Parliament? Brexit and the End of the History of the British Political Model
}

Pieter Lagrou

The fact that the proposal to leave the European Union obtained a narrow majority of 51.89 per cent in the referendum of 23 June 2016 was initially seen as a major crisis of the European Union. Two years later it is increasingly clear that Brexit is foremost a major crisis of British parliamentary democracy. The idea that the plebiscite is a superior form of democracy is profoundly alien to the British political tradition of parliamentarism, as a very explicitly indirect form of democracy. For liberals during the French Second Empire or the German Third Empire, the recourse to referenda was the hallmark of autocracy and antinomic to the idea of representative government. The brutal right of majorities to dispose of minorities was long seen in the United Kingdom as a continental disease, somehow linked to traditions of revolutionary and nationalist violence, electoral versions of the 'revolutionary surge' (levée en masse), at odds with the gradualism of representative politics in the United Kingdom.

The 2016 referendum therefore is at least as much related to the 2011 referendum on alternative voting than it was to the 1975 referendum on European Community membership. After all, David Cameron resorted to the solution of a referendum to solve a problem within the Conservative Party through popular arbitration, thereby implicitly admitting that the first-pastthe-post voting system in the UK was paralysing in this regard and British parliamentarism chronically unable to reform itself. The prospect of Brexit has thrown both Labour and the Conservative Party into disarray, unable to formulate a clear answer on what the popular mandate meant, in terms of timing or in terms of the new relationship with the EU (customs union, single market, ECJ jurisdiction, freedom of movement), thereby admitting a legitimacy deficit of representative compared to direct democracy. After June 2016 it seemed as if questioning the timing or precise perimeter of the popular decision to 'leave' was no less than a betrayal of the people by illegitimate political elites usurping power. The strange halo of unquestionable authority surrounding the referendum result in the UK since 2016, compared to the blatant disregard for referendum results on the constitutional treaty in France and the Netherlands in 2005, reveals the exponential erosion of the legitimacy of parliamentary democracy over the last decade worldwide, rather than some profound difference between the United Kingdom, on the one hand, and France and the Netherlands, on the other.

The fallout of the Brexit referendum proves, above all, that a plebiscite creates infinitely more problems than it can solve. The list of referenda creating inextricable complications for the problems they proposed to solve is long. The Upper Silesia plebiscite of March 1921 is an interesting precedent for Brexit. The overall result showed a crushing victory for 'remain' (with Germany rather than the new Polish State), but the allies decided to break down the result to the district level and dismember Upper Silesia, with the Eastern districts (where a majority had voted 'leave') joining Poland. An Upper Silesian solution to Brexit offers stimulating scenarios for Northern Ireland and Scotland.

The 'informative popular consultation' organised in Belgium in March 1950 over the return of King Leopold III is an equally interesting precedent. The Belgian constitution of 1830, drafted under British inspiration, did not include any reference to the possibility of holding a 
referendum. The king's wartime attitude had discredited him in the eyes of the allies and part of Belgian public opinion, who viewed him as a 'fascist'. The Catholic Party, which had been weakened in the interwar years by fascist and Flemish nationalist rivals, had rebranded itself in December 1945 as the Christian Democratic Party and chose the unconditional support for the king's return as its post-war rallying cry. This intransigent position landed them in the opposition for two years, but by June 1949 it allowed them to take control of the Senate and fall one seat short of the absolute majority in the Chamber of Deputies, with just 43 per cent of the vote. In March 1950 the Leopold 'remain' camp obtained 57 per cent of the vote, while the 'leave' camp scored just 42 per cent. The victory for 'remain' was overwhelming in Flanders, the most populous part of the country, with 72 per cent, but 'leave' won in Brussels and the Walloon part. Cashing in on their 'informative popular consultation' victory, the Christian Democrats organised new elections in June 1950, which, unlike Theresa May's attempt in June 2017, gave them the absolute majority in both chambers, with 47 per cent of the popular vote. Armed with what the party saw as a double popular mandate, the new government organised the triumphal return of the king on 22 July 1950. Popular unrest, a general strike and mass demonstrations resulted in the death of three protesters by police bullets. In the night of 30 July Leopold finally abdicated to the benefit of his son Baudouin.

If the Belgian 'informative popular consultation' of March 1950 should have been a cautionary tale for Brexiteers, it is so especially because of its aftermath. The victory in the referendum proved to be a particularly poisoned chalice for the winners. For an instant, in a country that had adopted proportional representation in 1899, even before the introduction of universal male suffrage (one man, one vote), the Christian Democrats managed to impose majority rule on a divided country with a long tradition of political compromise. The idea that in Belgium majorities could dispose of minorities was a perilous one, all the more so since the party - in spite of strong reticence voiced by several of its heavyweights - chose to put the personal fate of the head of state at stake by way of a popular consultation. This was an extravagant strategy of polarisation and politically every bit as irresponsible as the Brexit referendum. In a parliamentary monarchy with 'united makes strength' (L'Union fait la Force) as a motto, the monarch is supposed to be the symbol of national unity, above political partisanship. From 1950 to 1954 the Christian Democrats were condemned to govern the country with an absolute majority and to manage both the spoils of victory and the stain of humiliation. July 1950 had disproven its promise that a popular majority is all it takes to enforce a decision in a democracy. Democracy, after all, is more than majority rule. It is bound by a constitution, by political tradition and by respect for the country's allies, political and regional minorities. The party was voted out of power in 1954 and spent another four years in the opposition. By the late 1950s the strategy of ruling by referendum had fissured the party and created immense frustration in Flanders. An overall referendum victory, and a crushing victory in the most populous part of the country, had indeed resulted in Leopold's exit and thus, inescapably, in the victory of the minority. If majority rule was to triumph at last, only Flemish independence could offer real guarantees. The March 1950 plebiscite contributed more than any other event to the weakening of the Christian Democratic Party, the breakthrough of a new Flemish nationalist party, the split of Christian Democracy into a Flemish and Francophone party and, in the long run, the dismemberment of Belgium.

The Belgian Christian Democrats in 1950 and the Tories in 2016 saw the referendum as a short-term strategy to overcome internal party divisions and thus strengthen their chances to win a general election, based on the promise that a clear referendum victory would translate into bold and simple political decisions. Leopold's unconditional supporters and the UK's Brexiteers both soon discovered they could not deliver on this simple promise; that politics involve complex negotiations quite beyond the control of those given a popular mandate. Once it turned out that exiting the EU or making Leopold remain were not that simple, the parties were again doomed to be divided between extremists who remained true to their promise but utterly uninterested in the possibility of turning it into a working political arrangement, and realists who took the risk to 
appear as traitors to the will of the people. The promised omnipotence turned into impotence and electoral humiliation. There are reasons to believe that the Brexit referendum will similarly lead to the breakup of the party that initiated it and, in the long run, will probably do more harm to the unity of the UK than to that of the European Union.

For all the comments Brexit has elicited on the UK's relation to Europe, it is surprising so little has been written on what Brexit teaches us about the UK's understanding of democracy. If indeed democracy is as simple as that - put a question to a referendum and all complex political issues obtain a clear answer - why is it that for centuries we have wasted our time and money on convoluted systems of representative parliamentary democracy? Referenda almost systematically create more problems than they solve. When they deal with relatively straightforward social or ethical issues - should women and doctors who choose to terminate a pregnancy go to jail? Should marriage be restricted to people of the opposite sex? - they have the potential to overcome a constitutional or parliamentary deadlock and allow for the law to catch up with changing mores. But even for this strand of issues a generalised recourse to plebiscites is incompatible with what many hold to be the very essence of democracy. A referendum proposing to reintroduce the death penalty or to strip repeat offenders of their citizenship would probably obtain large victories in many countries but at the same time make democrats wince. In the end this comes down to the question on which ethical issues should be written into the constitution and which not. Ultimately, the argument that banning the death penalty should be a constitutional principle and banning abortion not is of a philosophical rather than a political order. When the very architecture of the political system is at stake, however, Brexit shows that a referendum as the expression of popular will functions much like an oracle as the expression of divine will: the real issue is not what has been uttered but how it is interpreted. The recourse to the referendum as a panacea is therefore an admission of impotence. Parliamentary politics are in turmoil all over the world, but the UK's voting system seems particularly dysfunctional when faced with complex issues such as the belonging of Scotland or Northern Ireland to the United Kingdom or any of the above to the European Union. The post-referendum paralysis of both Labour and the Conservative Party shows how the logic of direct and indirect democracy are inherently incompatible. A first-past-the-post electoral system was supposed to lead to a binary and centripetal political landscape, thereby permanently marginalising the political extremes and avoiding the woes of proportional representation, as exhibited in the Weimar Republic in Germany in 1933 and so forth. Both in the United States and in the United Kingdom that presupposition no longer holds. The binary political landscape has allowed the lunatic fringe to take control of the party machine and left political parties perfectly unable to steer a sensible political course.

The referendum on Catalan independence of October 2017 led to a fierce police crackdown and a judicial saga of Catalan protagonists seeking political asylum in other European countries, Spanish extradition requests and predictions of total collapse of the Spanish nation state. Yet, Spanish democracy, with far-reaching regional devolution and extensive proportional representation, seems, not even four decades after the transition from brutal dictatorship, to have so far weathered the challenge to its territorial integrity through a referendum considered illegal much better than the UK has managed the fallout from the Brexit referendum called by its own prime minister. The controversial nature of the referendum might be part of the reason. Unlike the Brexit referendum its legitimacy was contested, and its opponents boycotted it rather than vote against it. Those who called for the referendum saw it first and foremost as a means to strengthen their hand in complex negotiations with Madrid and Brussels. Yet in spite of its contested legitimacy, at least the Catalan referendum made a concrete proposition ('do you want Catalonia to become an independent state in the form of a republic'), which the Brexit referendum did not ('should the United Kingdom remain a member of the European Union or leave the European Union'), creating the illusion that the nature of the relationship the UK would 
establish with the European Union once it left the Union was self-evident or up to the UK alone to decide.

The accumulation of damage the UK has inflicted upon itself - the Brexit referendum, the untimely activation of Article 50 by which British negotiators effectively cornered themselves, the June 2017 anticipated elections and the utter incapacity, more than two years after the referendum, to come up with anything even remotely resembling a serious proposal for a future relationship with the EU - is a frightening sight. Seen from the European continent, Europe not only seems at risk to lose a valuable partner in the European experiment - an experiment that has its manifest shortcomings but that is undeniably the only future oriented experiment on the table today. It has already lost a model: one of political stability and liberalism, a democracy built on centuries of parliamentary tradition and representative government so unlike the spasmodic and violent constitutional histories of the continent. Europeans have been cradled to distrust continental politics and look across the Channel and the Atlantic for political stability, liberal resilience, checks and balances. Brexit and Trump have brought a brutal awakening. The problem is no longer Europe, it is democracy itself, in Washington, London, Belfast and Edinburgh no less than in Berlin and Paris, let alone Rome, Budapest and Warsaw. 